\title{
安全面と衛生面を含むリスクアセスメント手法に関する一考察*
}

\author{
大村 宏之 ${ }^{* 1}$, 福田 隆文 ${ }^{* 2}$, 蓬原 弘一 ${ }^{* 3}$, 杉本 旭 $^{* 4}$
}

\section{A Study of Risk Assessment Method Containing Hygiene Aspect and Safety Aspect}

\author{
Hiroyuki OMURA*1, Takabumi FUKUDA, Koichi FUTSUHARA and Noboru SUGIMOTO \\ ${ }^{* 1}$ The Japan Food Machinery Manufacturers' Association \\ Shibaura 3-19-20, Minato-ku, Tokyo, 108-0023 Japan
}

\begin{abstract}
The most characteristic point of food processing machines is that they require hygiene measures for risk reduction against contamination of manufactured food products for consumers, as well as safety measures for risk reduction to ensure safety for operators. The measures of risk reduction for safety aspects do not always match the risk reduction measures for hygiene aspects. The protective measures of safety aspects may increase the hygiene risk. Therefore, ISO 14159 has defined to decide the suitable protective measures for risk reduction by comparing both safety and hygiene. However, not only ISO14159 but also other standards do not illustrate a concrete method by comparing safety risk and hygiene risk. Harm contents differ between safety risk and hygiene risk, so methods of safety risk estimation are inapplicable to hygiene risk estimation. Consequently it has been an important issue in Food-processing machine industry to develop method of risk assessment by comparing the safety risk and hygiene risk, because of these circumstances. Authors devise the reduction measure of the hygiene aspects to be included in the process of the limits of the machine. We consider it is possible to perform both risk assessments, according to risk reduction process described in ISO 12100-1, without comparing both different risks. This paper mentions about the unprecedented assessment method including different risks.
\end{abstract}

Key Words : Risk-Based Design, Risk Assessment, Safety Engineering

\section{1. 緒言}

機械類の安全性を定める国際規格(以下，機械安全規格)はそれぞれの目的に応じて 3 つの階層による体系化が はかられている。一般的な安全側面に関する基本概念及び原則等を定める規格は “基本安全規格(以下，タイプ A 規格)”，類似の製品及びプロセスに広く適用可能な安全面に関寸る規格は “グループ安全規格(以下，タイプ B 規 格)”，そして特定の機械の安全側面を含む規格を “個別機械安全規格(以下，タイプ C 規格)”に分類することを ISO12100-1:2003 ${ }^{(1)}$ は示す. このタイプ B 規格の一つとして, 機械で製造した製品の消費者を対象とする衛生面の リスク(以下，衛生リスク)が生じる可能性のある全ての機械を対象とする ISO14159:2002 (2)(以下，衛生 B 規格)が 2002 年に成立した。衛生 B 規格は，衛生リスクについて特に定義を行っていないが，機械によって生産した製品 (食品, 医薬品, 化粧品等)の消費者(Consumer)を対象とすることを箇条 1.の “適用範囲” は示す.この規格により, 機械安全規格に機械作業者が被る身体的傷害及び健康障害に関するリスク(以下, 安全リスク)の他に, 衛生リス クが含まれることが明確になった.

しかし安全と衛生双方のリスクを低減させるため, 衛生 B 規格が Introduction において “The assessment of the respective safety and hygiene risks shall indicate their relative significance”と記すように, 衛生 B 規格の Figure 1 は一



\footnotetext{
* 原稿受付 2010 年 7 月 12 日

*1 正員, (社) 日本食品機械工業会 (广 108-0023 東京都港区芝浦 3-19-20)

*2 正員, 長岡技術科学大学技術経営研究科 (T 940-2188 新潟県長岡市上富岡町 1603-1)

*3 正員, 明治大学理工学部 (广 214-8571 神奈川県川崎市東三田 1-1-1)

$*_{4}$ 正員, フェロー, 明治大学理工学部

E-mail: ohmura@fooma.or.jp
} 
プロセスを示寸．だが，このようなリスクアセスメントを実施するための具体的実施モデル及び，衛生リスクそ のものの具体的な見積もり方法について, 衛生 B 規格のみならずタイプ A 規格を含む他の機械安全規格は例示し ない，そのため食品加工機械製造業界では，これらリスクアセスメントを実施するためのプロセスと衛生リスク 見積もり方法をセットにしたモデル開発が喫緊の課題となっている.

以上に鑑み，本論文では我が国食品加工機械製産業における安全規格に基づく設計活動の普及に資することを 目的に, ISO12100に基づく安全及び衛生リスクを考慮した食品加工機械に対するリスクアセスメントプロセスの 理論を構築し，また衛生リスクを見積もるための手法例を示す.

\section{2. 安全リスクと衛生リスクの主な特徴と差異}

安全性を考慮した機械の設計は，はじめに使用者情報に基づき“機械の制限”及び “意図する使用”（これらを 以下，制限仕様）を指定し，次いで “ライフサイクルに渡る安全性” “機能遂行能力” “使用性” “製造運転等のコ スト” (以下，リスク低減 4 要素)を考慮して最大限リスク低減をすることを ISO12100-1 の箇条 5.1.3 及び5.1.4 は 定める. 食品加工機械の場合, リスク低減 4 要素を考慮した安全リスクの低減だけでなく, 同時に衛生リスクの 低減を図らなければならない，だが，衛生リスクは安全リスクとは大きく異なる．従来機械安全規格が扱ってき た安全リスクは，主に機械の駆動部や電気により作業者が被る危害を対象としており，危害を被る対象が限定さ れている．また安全リスクを低減するための方策(以下，保護方策)には，主に “可動部の隔離”，及び “可動部の 停止”がある.

一方, 衛生リスクは, 危害を被る対象は不特定多数の製品消費者になるため, 対象を限定することはできない. また，主な衛生リスクを低減するための設計上の保護方策は，衛生 B 規格の箇条 5.2.2〜5.2.3 より製品を污染す る物質を除去するための “清掃・洗浄し易い構造”, 確認のための “容易に接近可能な構造” 及び, 細菌污染及び 増殖を最小限とするための“製造工程の滞留時間を最小限とする構造”等と言える.

このように安全リスクと衛生リスクは, リスクの性質, リスクの対象, 及び保護方策が根本的に異なる. その ため安全リスクを低減させる事だけを考慮し, 製品加工に係わる可動部をガードで覆うと作業者の容易な接近を 妨げ，あるいは可動部を安易に停止させる構造とすると食品の滞留時間増加を招き，いずれも細菌増殖等の衛生 リスクを増大させる恐れがある，このように一方のリスク低減のみを考慮した保護方策は，時として他方のリス ク増大を招く恐れがある. 設計者はこのような特徴を考慮し, リスクアセスメントを実施しなければならない。 なお，本論文では，“安全(性)”という用語は機械の安全面と衛生面双方に対し，受け入れ不可能なリスク (unacceptable risk)のないことを示寸用語として用いる.

\section{3. 安全リスク, 衛生リスクの低減プロセスとその概念}

\section{$3 \cdot 1$ 衛生的危険源及び危害}

衛生 B 規格は，衛生面の危害を引き起こす潜在的な根元である “危険源”について次の 3 原因(cause)に基づく と規定する.

一生物的原因(B : Biological causes) : 病原体, 腐敗微物又はその毒素.

一化学的原因(C : chemical causes) : 洗浄及び消毒剂.

一物理的原因( $\mathrm{P}$ : Physical causes) : 原材料, 設備及び有害小動物等に由来する外部物質.

従って衛生的危険源とはこれら “3 原因に関連する食品污染を招く潜在的根元” と解することができる. 具体 的には, 食品又は洗浄液が滞留し腐敗微生物の増殖を招く恐れのあるデッドスペース, パッキン等のシール材を 破損させる恐れのある継ぎ手や接続部の構造, 及び意図する使用条件下で破損する恐れのあるコーティング等で あるままたこのような 3 原因により污染された食品をここでは “衛生的危険源に関連する不適合(Non-conformity related to the hygienic hazards)”之呼ぶ.

従って規格が定める衛生面の危害(以下, 衛生的危害)は, 衛生的危険源に関連する不適合品により生じる消費 者の障害(健康障害, 及び口内損傷等の傷害)と言える. 


\section{$3 \cdot 2$ 食品産業における衛生リスク}

表 1 は，国民生活センターが 2005 年〜2008 年に公表したリコール情報を集計，分類したものである．同表で は食品のリコール原因を 3.1 節に記す “衛生的危険源に関連する不適合”と，これに含まれないその他の消費期 限の誤表示，原料の誤使用等の “管理面に関寸る不適合(Non-conformity related to the management aspect) ”に大別 する．衛生的危険源に関連する不適合は，小項目を設け細分化し，また各小項目には原因別に 3 原因の属性を表 寸記号(B，C，P)を記した. なお，リコールの際に企業が公表した多くの社告は詳細な発生原因を示さないため, リコール原因が食品加工機械に由来するか判別できない，そこで，表 1 では，食品加工機械に関連する可能性の ある全てを“衛生的危険源に関連する不適合”にまとめた.

この “衛生的危険源に関連する不適合” の中で，消費者が障害を被ったことを記載したものは，2007年が食中 毒事故, 及びこんにやくゼリーによる窒息事故の 2 件, 2008 年は中国産冷凍餃子への殺虫剤混入事故, 及び異物 混入による体調不良の 2 件, 2009 年は 0 件であった. これらの事故のうち, こんにゃくゼリーによる事故は製品 の問題であり, 餃子への殺虫剂混入は意図的な事件であるため除外すると, 衛生的危険源に関連する不適合に起 因すると考えられる事故は 2 件であった.

以上より，衛生的危険源に関連する不適合品は，消費者に “障害をたらす恐れのある不適合”，及び “障害をも たらす恐れの低い不適合”に大別できると考えた。“障害をもたらす恐れの低い不適合”には，人体に無害な酵母 菌污染による異臭, 異味や, 人体に無害な物質の混入等がある. 衛生リスクの対象を食品の消費者とする場合,

“障害をもたらす恐れの低い不適合”の衛生リスクは，無視可能なレベルとして見積もられる可能性が高い. だ が，現実にはこのような不適合であっても，時には食品事故として報道され，食品加工機械を用いて食品を生産 する食品加工業者(以下, 機械ユーザ) は直ちに対象となる全ての製品を回収しなければならず, リコール実施は, 機械ユーザに多額の経済的損失をもたらすことがある.

実際に 2007 年 1 月に公表された日本コカ・コーラの事故では, 食品衛生法に適合したエラストマの破片混入に より，同社は 134000 本に及ぶ製品を回収したが，誤飲しても健康に影響ないこと等を社告に記載している.

従って機械ユーザが食品機械製造業者(以下，機械メーカ)へ機械を発注する際の衛生面の要求は，消費者に障 害をもたらす不適合品が発生しにくい構造は当然として, “障害をもたらす恐れの低い不適合”も発生しにくい構 造を包含したものとなる.

以上より，設計のために衛生リスクを見積もる際，“消費者に障害をもたらす恐れの低い不適合”を生じるリス クも，リコールにより機械ユーザが被る可能性のある経済的損失を衛生リスクとして評価できなければ，現実の 取り組みと乘離した手法となってしまう恐れがある.

\section{$3 \cdot 3$ 衛生リスクの対象}

食品衛生法第 3 条が規定するように, 食品加工機械を使用する機械ユーザは安全な食を提供する社会的責務を 負う。その責務に背く機械ユーザは，例え人的被害が生じなくても社会から容赦ない制裁を受けることが近年の 不二家，ミートホープ等の例からも明らかである．従って機械ユーザを対象とする衛生リスクは，消費者に対す る衛生リスクを包含すると考えられる.

食品産業界における実用的な食品加工機械の衛生リスクを見積もるためには，衛生リスクの対象を“消費者” だけでなく“機械ユーザ”まで含め, 消費者の健康を損なう恐れの低い衛生的危険源に関連する不適合も対象と することが重要であると考える，従って本論文では衛生リスクの対象を“機械ユーザ”と定めた.

\section{$3 \cdot 4$ 安全, 衛生を考慮したリスク低減プロセス}

一般的なリスク低減プロセスは ISO 12100-1 の Figure 2(以下，反復的プロセス)が示し，衛生リスクを考慮した リスク低減プロセスは衛生 B 規格の Figure 1 (以下, 衛生プロセス)が示寸. 衛生プロセスは, 衛生リスクの低減 を先ず検討し，採用する衛生面の保護方策が安全面の新たな危険源の創出又は安全リスクの増大を招く場合，安 全と衛生リスクの比較に基づきリスクの高い一方を優先しリスク低減のための保護方策を検討することを定める.

この衛生プロセスに従うためには，安全・衛生双方のリスクを相対的に比較可能なレベルとして見積もること が可能でなければならない. リスク要素の “発生確率” は, 同一のものを用いることが可能である. だが “危害 のひどさ”は，安全リスクは作業者が被る傷害の程度であり，他方の衛生リスクは，機械ユーザを対象とする場 
合, 経済的損失となる. 一方, 衛生リスクの対象を消費者とする場合は, 安全リスクと類似する健康障害を扱う ことができる．しかし，食品事故は 2000 年に生じた雪印事件のように 1 万人を越える多数の被害者が生じる可 能性があり，ひどさのレベルに社会的な規模を含む，安全と衛生双方のリスク見積もりに使用可能な “危害のひ どさ”を定めなければならない。

また, 衛生プロセスは衛生リスクの低減に焦点が置かれているため, 安全リスクの低減がおろそかになる恐れ も考えられる.このような衛生構造を優先する傾向は, 業界の古くからの特徵とも言える. 我が国における食品 産業の労働災害発生件数が製造業の中で最も高い(3)原因の一つが，この点にあると推測できる.

労働災害を防止するための安全リスクの低減は，日本のみならず世界各国で制度として確立されており，この ような安全性の確保は，国際的に製品を流通させるための条件ともなっている．このような安全リスクは，社会 全体が危害に晒される衛生リスクとは全く性質が異なる.

以上より，このような全く異なるリスクを比較により保護方策を求めることは困難であると言えることから， 筆者等はそれぞれのリスクを分離して，独自に取り扱うことを可能にするため，反復的プロセスを用いることを 検討した.

1 節に示す “洗浄・清掃し易さ” 等の衛生リスクに対する主な保護方策は, 機械ユーザが定める衛生管理上の 作業を支援する構造とも言える。“衛生管理上の作業を支援する”とは, 機械ユーザが定める条件で, 目標を達成 する機能, 寸なわち, 定められた時間内での洗浄・清浄, 及び清浄度の確認が可能で, 食品に異物が混入し難い 構造，等である．このように衛生リスクを低減するための構造の多くは，顧客が提示する仕様により具体的に定 まる事項であることに筆者等は着目した，そこで衛生構造を機械類の制限の決定(Determination of the limits of the machine)のステップ(以下, 制限仕様ステップ)で扱うことで, 衛生リスクと安全リスクのアセスメントと分離する ことが可能と考えた.

\section{$3 \cdot 4 \cdot 1$ 制限仕様への衛生構造検討プロセスの付加}

ISO 12100-1 の箇条 5.2 は，機械設計者は機械ユーザから受け取る情報に基づき “制限仕様”を先ず定めること を示寸. 制限仕様の概要は, ISO14121-1 ${ }^{(4)}$ の箇条 5.が示しており “使用上の制限(Use limits)” “空間上の制限(Space limits)”“時間的制限(Time limits)”“その他の制限(Other limits)”である.

制限仕様ステップに衛生構造検討の作業を含めるため, ISO14121-1 が示寸制限に, 次に示寸衛生面の制限(以 下，衛生仕様)を追加する，すなわち “使用上の制限”には使用方法，加工寸る食品材料，洗浄方法及びそれによ り達成される清浄化レベル等の条件, 清浄化レベル確認方法, 殺菌条件, 使用環境, 並びに許容可能な衛生リス ク。“空間上の制限には” 清掃及び衛生面に関連する保守及び検査のための空間上の条件. “時間的制限”には衛 生性維持に係わる部品及び材質の経年劣化並びに清浄化・検査のための時間上の制約等である.

なお, 制限仕様ステップにおいて衛生構造を定める際には, リスク低減に基づいた安全性の達成をはかるため, 衛生リスクのみを対象とする反復的プロセスを適用する。すなわち図 1 に示すように “機械類の制限の決定”に 衛生構造を定めるための 3 ステップがあり, 以降の 3 ステップで安全リスク低減活動を行うものである.

\section{$3 \cdot 4 \cdot 2$ 制限仕様ステップに衛生構造検討作業を付加した場合の安全・衛生リスク低減の流れ}

図 1 に示寸, 制限仕様ステップに衛生構造検討のプロセスを付加した場合の衛生リスク及び安全リスク低減の 流れを次に示す.

はじめに衛生構造を検討するために必要な情報, 及び安全リスクに関連する制限仕様を機械ユーザから得た後, 制限仕様として扱う衛生構造を 3 ステップに基づき, 適切な保護方策を検討寸るものとする. なお, 衛生リスク 見積もり手法については 4 節に例示寸る. またリスク低減に基づく衛生構造を検討する際は, 安全リスクは除外 し, 衛生構造及び衛生面の使用上の情報を検討する，安全リスクの低減は，衛生構造を含む制限仕様が定まった 後, 反復的プロセスに従う.

図 1 は, 反復的プロセスに従い，3つの主なループを持つ[図 $19(\mathrm{~A}),(\mathrm{B}),(\mathrm{C})]$. なお，ループ(A)は意図した 安全リスク低減が達成されるが，保護方策により他の安全リスクを生じる場合.ループ(B)は意図する安全リスク 低減が達成されない場合. そしてループ(C)は, 意図した安全リスク低減が達成され，かつ保護方策が他のリスク を生じない場合の経路である. 
Table 1 The attribute of the cause concerning a hygienic nonconformity matter in Japan

\begin{tabular}{|l|c|c|c|}
\hline The cause of recall & 2007 & 2008 & 2009 \\
\hline $\begin{array}{l}\text { B : Insufficient overheating and } \\
\text { sterilization error }\end{array}$ & 20 & 2 & 0 \\
\hline B : The growth of mold & 17 & 13 & 5 \\
\hline C : Contamination of food by antibiotic & 2 & 0 & 0 \\
\hline $\begin{array}{l}\text { C : Contamination of food by } \\
\text { chemical substances }\end{array}$ & 4 & 32 & 0 \\
\hline $\begin{array}{l}\text { C, P : Contamination of food by } \\
\text { allergens }\end{array}$ & 14 & 3 & 7 \\
\hline $\begin{array}{l}\text { C : Contamination of food by food } \\
\text { additives }\end{array}$ & 5 & 3 & 1 \\
\hline B, C : Unusual flavor and taste & 6 & 8 & 4 \\
\hline P : Contamination of food by pests & 2 & 0 & 0 \\
\hline $\begin{array}{l}\text { P : Contamination of food by } \\
\text { materials and parts of the machine }\end{array}$ & 5 & 2 & 4 \\
\hline P : Contamination of food by rust & 0 & 0 & 0 \\
\hline $\begin{array}{l}\text { P : Contamination of food by } \\
\text { elastomers and polymers }\end{array}$ & 9 & 3 & 0 \\
\hline $\begin{array}{l}\text { P : Contamination of food by steel } \\
\text { fragments }\end{array}$ & 17 & 5 & 3 \\
\hline P : Contamination of food by glass & 7 & 1 & 1 \\
\hline $\begin{array}{l}\text { P : Contamination of food by } \\
\text { foreign materials }\end{array}$ & 12 & 8 & 0 \\
\hline $\begin{array}{l}\text { Non-conformity related to the } \\
\text { management aspect }\end{array}$ & $\mathbf{1 6 9}$ & $\mathbf{6 8}$ & $\mathbf{5 6}$ \\
\hline & 295 & 148 & 81 \\
\hline
\end{tabular}

B : Biological causes, C : Chemical causes, $\mathrm{P}$ : Physical causes

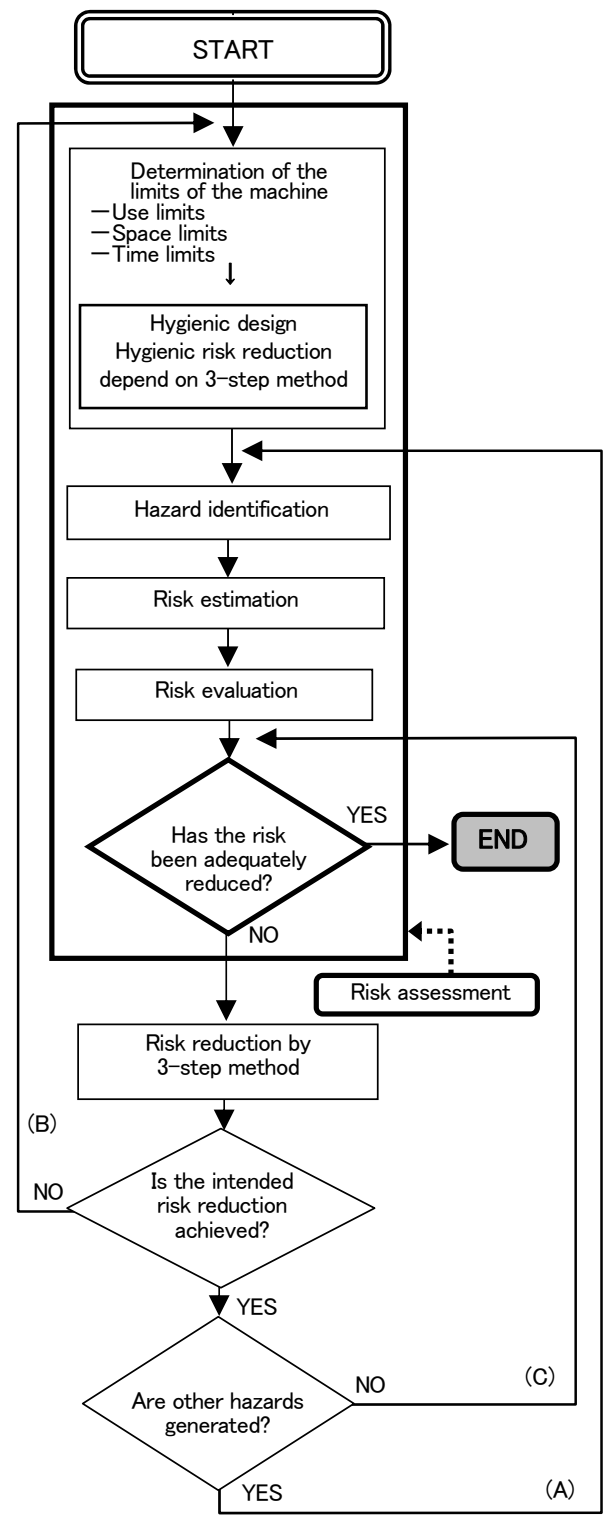

Fig. 1 Proposed risk reduction process for the food processing machinery

衛生リスク及び安全リスクの一方に対する保護方策は，1.節に示すように，時として他方のリスクを増大させ ることがある。そのため衛生リスクに対する保護方策により安全リスクの適切な低減ができずループ(A)及び(B) へ向かわなければならない局面が生じることが想定できる.

ループ(B)へ向かう局面の例としては, 制限仕様の衛生構造が原因で, 合理的に選択可能な保護方策では安全リ スクを許容可能なレベルにまで低減することが困難である場合が考えられる．食品加工部周辺のガード類に付着 する食品残渣，塵埃が食品加工部へ落下寸ることによる異物混入が考えられる．このような危害を回避するため の対応の一つを具体例として述べる．この危害を防止するための本質的安全設計方策として，食品加工部周辺に ガード類を設けないことを制限仕様に定めることがある．また，作業中における作業者の動作要求により，ライ トカーテン等の保護方策でも安全リスクを目標レベルまで低減できない事がある.

このような場合，設計者は制限仕様の決定に戻り機械ユーザとの協議により，制限仕様である安全リスクの目 標值を変更，衛生リスクの目標值，又は衛生構造を変更，あるいは機械の形状，作業者の動作要求等の変更を行 
う. 制限仕様を再設定した後に, 再度安全リスク低減に取り組む. なお, 衛生リスクの目標值を変更し, 可動式 ガード等の設置を認める場合, その変更により生じる衛生リスクへの対応, すなわちガードの洗浄・清掃, 及び 清浄度に関する検查等を機械ユーザが負担することを制限仕様の一つとして明確にする必要がある.

一方，ループ(A)は，(1) 安全リスク低減のために検討した保護方策そのものが不適切だった場合，又は(2) 安 全リスクに対する保護方策が衛生リスクを新たに生み出す場合, 等が考えられるが, ここでは(1) は除外する. (2) の場合に関する事例として, 安全リスク低減のため施錠式リミットスイッチ付きガードを食品加工部周辺に設置 する場合を想定する．施錠式リミットスイッチにはキーの差し込み部が清掃困難なデッドスペースとなるため, この保護方策の採用は，新たな衛生面の危険源を生じさせることになる.

この例では, 設計者はループ(A)により保護方策の検討に戻り, 新たな衛生面の危険源を生み出さない, 又は衛 生リスクが低くなるようなその他の方策を検討する，それでも新たな衛生リスクが許容できない場合は，ループ (B)により制限仕様の変更を行うことが必要になる.

以上のように図 1 は, 反復的プロセスに従い安全・衛生双方のリスクを比較することなく, 双方に対し適切な 構造を定めることができると考えられる，また，上述するように “制限仕様” は，上記リスク低減のプロセスを 反復することによって最終的に定まるものとする.

\section{4.＼cjkstart衛生リスク見積もり手法例}

前節において衛生リスクを考慮した設計を行うために衛生リスクを制限仕様で処理するプロセスを示した．こ のプロセスを実施するため, ここでは衛生面の保護方策を定める際に指標とする衛生リスクを見積もるための手 法例を示す，なお，リスク見積もりの際の各リスク要素の変数を“リスク変数”と呼ぶ.

\section{$4 \cdot 1$ リスク見積もり手法}

工業統計表, 産業編(2006) $)^{(5)}$ によると, 機械メーカにおける従業員 50 名以下の中小企業の事業所が全体に占め る割合は全体の 801 件中 754 件と, 実に $94 \%$ にのぼる. 産業の大多数を占める中小企業が使用可能なリスクアセ スメント手法でなければ，実用的な手法とは言えない。 “マトリクス法” “数值的スコアリング法” 等多数のリス クを見積もるための手法が知られるが，ISO/TR 14121-2:2007 (6) の Annex A の A.3 が記すように “マトリクス法” は最も簡便で, 迅速な方法として知られる. そのため衛生リスクを見積もるための手法に, ここではマトリクス 法を用いる。

また，マトリクス法のモデルは，ANSI B 11.TR3：2000"(7)，MIL-STD-882D : $2000 ，$ IEC61508-5 : 1998 等の複 数の規格が例示する. これらはリスク変数を表す用語だけでなく, リスク変数の分類及び定義まで異なる. これ らのうち ANSI B 11. TR3 は, 食品加工機械と同じ産業機械に分類される工作機械を適用範囲と定め, 最も対象と 寸る機械が近く, また同規格が示すリスク変数はそれぞれ 4 段階と最も簡便なマトリクスとなっていることから, 食品加工機械のリスク見積もり手法モデルに用いるには最適と考えた.

\section{$4 \cdot 2$ リスク変数の程度分類}

“危害のひどさ $(\mathrm{S}) ”$ 及び “発生確率(P)” のリスク変数の分類は ANSI B 11 TR3 が示す変数を基本的に用いるも のとし，リスク変数の大小関係及びそれぞれの内容を次のように定める. なお，リスク变数は多值による重み付 けを行い“危害のひどさ”は $\mathrm{Si}(\mathrm{i}=1$ 1 4), “発生確率”は $\mathrm{Pi}(\mathrm{i}=1$ 1 4)で表す.

\section{$4 \cdot 2 \cdot 1$ 危害のひどさ}

ANSI B 11 TR3 の箇条 7.2 は “危害のひどさ(S)”のリスク変数の大小関係を次のように定める.

S1:小災害(Minor) $<$ S2:中災害(Moderate) $<$ S3:重大災害(Serious) $<$ S4:大惨事(Catastrophic)

リスクの対象を機械ユーザとする場合のリスク変数のレベルを定める際，まず “重大災害”と“中災害”の境 をリコールの有無と定めた。なぜならリコールの実施は機械ユーザに多額の経済的損失をもたらす可能性がある 
からである．リコールにより機械ユーザが被る経済的損失額の大きさは，事故の内容により異なるが，AIU 保険 会社が公開する「CPI(Contaminated Products Insurance)の事故例」 ${ }^{(8)} に$ 記載される 4 件の事例では, いずれも食品リ コールにより 1,000 万円以上の経済的損失が生じた内容となっている. 従って本論文ではリコールの実施により 機械ユーザが被る経済的損害を最低 1,000 万円とした.

また, リコールが害施される場合, 特に生物・化学的原因については, 消費者の健康障害を招く可能性がある. このような場合，リコール費用に障害を被った消費者に対する損害賠償額を加算する．消費者に障害が生じた場 合の損害賠償額の 1 人当たりの平均額は, (社)日本食品衛生協会が公開する「損害賠償事故例」を参考に定めた. 当資料は旅館, 飲食店, 仕出屋, 給食施設, 食品製造所等における損害賠償事故例を示すが, 食品製造所の事故 例の記載が少ないため，事故例が多い “飲食店” “仕出し屋”における 2004 年から 2005 年にかけての総計 172 件の事例を集計し求めた，その結果，生物，化学的原因による食品事故の平均補償額は 1 人当たり約 3 万円であ った.

さらに, 経済的損失の大きさにより「危害のひどさ」のレベルを定める場合, 上述する損失額の合計を持って 評価するのではなく，機械ユーザの規模を勘案する必要があると考える．なぜなら企業の規模により，経済的損 失に対する而性は異なり，中小企業の場合， 1,000 万円規模の損失でさえ深刻なダメージを被ることも想定され るからである. 内閣府国民生活局が 2008 年に発行した「食品・製品等のリコールに関する分野横断的指針につい ての調查研究 報告書」 ${ }^{(9)}$ の “参考資料” には, リコールに対する企業の意見として「中小企業がリコールをす ることは，コスト負担が増し，実質的に難しい」「社告を出すと莫大な経費を要し，倒産を免れない」等のアンケ 一ト調査結果が示される.これら意見からもリコール実施は中小企業に相当の経済的損失を与えることが伺える.

そこで機械ユーザが被る経済的損失の大きさを，従業員 1 人当たりに換算し，その大きさに応じて “被害の大 きさ”のレベルを定めた．工業統計表 企業統計編(2006) ${ }^{(10)}$ によると，食料品製造業の $95 \%$ 以上を占める資本金 金 10,000 万円未満の中小企業数は 21,580 社, 総従業員数は 682,978 名となっている. このデータから中小企業 1 社当たりの従業員数の平均を取ると約 32 名となる. リコールの実施に伴う経済的損失の最低額を 1,000 万円とす ることから，従業員 1 人当たりの損失額は約 31 万円となる．また，“重大災害”と“中災害”の境をリコールの 有無とするため，このレベルを “重大災害”の下限レベルの参考值とする．次に，危害の大きさの各レベルに敷 值を設け，また利用し易さを考慮し，従業員 1 人当たりの損失額をそれぞれ 10 の対数により表すこととした.

以上より “重大災害” のレベルの損失額を 1 人当たり $¥ 10^{5}$-以上 $¥ 10^{6}$-未満(Loss exceeding $¥ 10^{5}$ - but less than $¥ 10^{6}$-/man) と定める。

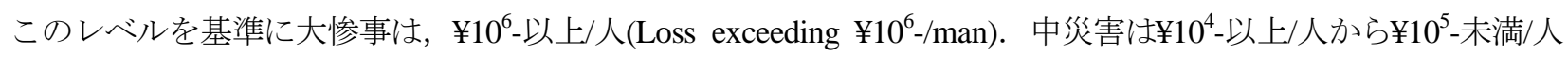

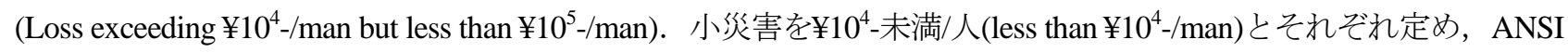
B11 TR3 が示寸危害のひどさと共に表 2 に示す.

なお，被害者への補償のみでリコールを伴わない衛生的危険源に関連する不適合品による食品事故の例には， 次のようなものが考えられる. 例えば出荷先が限定された店舗へ麺を卸す製麺業者のように, 製品のストックを 持たず，出荷先が限定された日配品を製造する機械ユーザ等である. 衛生的危険源に関連する不適合品が発生し ても，原因究明時には回収する製品がない場合がある.

Table 2 Suggested the criteria for severity of harm

\begin{tabular}{|c|c|l|l|}
\hline \multicolumn{2}{|c|}{$\begin{array}{c}\text { Severity levels } \\
\text { of harm (S) }\end{array}$} & \multicolumn{1}{|c|}{$\begin{array}{c}\text { Description of the severity of harm } \\
\text { for hygiene (For User) }\end{array}$} & \multicolumn{1}{c|}{$\begin{array}{c}\text { Description of the severity of harm for } \\
\text { safety(ANSI B 11 TR3) }\end{array}$} \\
\hline Minor & S1 & - less than $¥ 10^{4}$ - per one employee & $\begin{array}{l}\text { - No injury or slight injury requiring no more } \\
\text { than first aid }\end{array}$ \\
\hline Moderate & S2 & $\begin{array}{l}\text { - Loss exceeding } ¥ 10^{4} \text { - but less than } ¥ 10^{5} \text { - per one } \\
\text { employee }\end{array}$ & $\begin{array}{l}\text { - Significant injury or illness requiring more } \\
\text { than first aid }\end{array}$ \\
\hline Serious & S3 & $\begin{array}{l}\text { - Loss exceeding } ¥ 10^{5} \text { - but less than } ¥ 10^{6} \text { - per one } \\
\text { employee }\end{array}$ & - Severe debilitating injury or illness \\
\hline Catastrophic & S4 & - Loss exceeding $¥ 10^{6}$ - per one employee & $\begin{array}{l}\text { - Death or permanently disabling injury or } \\
\text { illness }\end{array}$ \\
\hline
\end{tabular}




\section{$4 \cdot 2 \cdot 2$ 危害の発生確率}

ANSI B 11 TR3 の箇条 7.3 は“危害の発生確率(P)”のリスク変数の大小関係を次のように整理し，示す. このリスク要素は内容を修正することなく用いる.

P1:ほとんどない(Remote) ＜ P2:僅かに( Unlikely) < P3:時々(Likely) < P4:可能性大(Very likely)

\section{$4 \cdot 3$ マトリクス法による衛生リスク見積りと評価の例}

表 3 はリスクを評価するマトリクスであり，リスク変数 Si，Pi の和をリスクインデックス(以下，RI)として数 值で示寸. ANSI B11.TR3 が示寸マトリクス(以下，ANSI マトリクス)のリスクレベル(以下，RL)をそのまま用い るが，相対的な評価し易さを考慮し各レベルをそれぞれ，High=I, Medium=II, Low=III, Negligible=IV,とローマ 数字の I, II, III, IV に置き換えた.

各リスク変数に割り当てた数字をそのまま用いると, ANSI マトリクスの RL は得られない. そのため ANSI マ トリクスと同一の RL が定まるよう “危害のひどさ (S)”のリスク変数 S1〜S4 に 1〜 5, “発生確率 (P)” のリス ク変数 P1〜P4 に 1 7 の数值を各々割り振り, ANSI マトリクスの RI を定めた. リスク変数を重み付けし， RI を各 RL に割り当てる方法は，各リスク要素の変数に割り当てる重み付けを変更することにより RL を必要に応 じて容易に修正することを可能とする.

さらに ANSI マトリクスでは，リスク変数を高から低の順に配置するが，本論文ではリスクの大きさを必要に 応じて拡大する等の修正作業を容易にするため, リスク変数を低から高の順に配置した.

また，ANSI マトリクスは，RLをHigh， Medium，Low， Negligibleの4つに分類し示すのみで，機械安全規格 作成に関する指針である ISO/IEC ガイド51:1999 ${ }^{(11)}$ の箇条 3.7 等が示す “許容可能なリスク (Tolerable risk)” がど の RL に相当するかを示さない. これも食品機械産業界において, リスクを評価する上での課題となっている.

1節に示すようにリスク低減目標, 寸なわち “許容可能なリスク” のレベルはリスク低減 4 要素により定まり, また衛生リスクにより生じる経済的損失一の而性が企業規模により異なることを考慮すれば，“許容可能なリス ク”のレベルを定めるのは機械ユーザ，あるいは社会(裁判所)と言える.

だが，より具体的な参考例の提示が産業界において求められている. また，保護方策の種類，及び残留リスク のレベル等に関する “合理的代替設計” 及び “許容可能と見な寸構造” の例を示寸指標の一つとなるタイプ C 規 格を作成するためにも，具体的なリスクレベルは不可欠である。筆者等は食品加工機械のタイプC 規格作成に携 わっていることから，タイプC 規格作成のためにも，リスクレベルの階層を以下のように定めた.

すなわち ANSI マトリクスの RL を IEC61508-5:1998 ${ }^{(12)}$ の附属書 B，B2 及び ISO/IEC ガイド 51 が示す “受け入 れ可能なリスク(Acceptable risk)”, “許容可能なリスク”の用語を用いて次のように分類寸るものである(表 4).

Negligible Risk は, IEC61508-5 の Annex B が, Broadly acceptable region と定めることから，レベル I を無条件で 広く受け入れることができるリスク(受け入れ可能なリスク)と見な寸.

この否定である “受け入れ不可能なリスク Unacceptable risk”を受け入れが全く不可能なリスクとし, レベルIV を割り当てる.

IEC61508-5 ではリスクを受け入れることで相応のメリットが得られる等のレベルを Tolerability region とするこ とからリスクレベルII を条件付きで許容可能なリスク，すなわち “許容可能なリスク”とした．このレベルはリ スクを受け入れる代わりにコスト等の大きな便益性を得る.

許容可能なリスクの否定である “許容不可能なリスク(Intolerable risk)” IEC61508-5 は，特別な状況以外正当 化できないとし，特殊な条件にのみ採用の可能性を残すため, リスクレベルIIIに割り当てた.

上述のリスクレベルを用いて行ったリスクの評価結果の妥当性について，機械メーカ，機械ユーザ，有識者か らなる組織にて検証を行っている. 
Table 3 Risk levels and categories of matrix

\begin{tabular}{|c|c|c|c|c|}
\hline $\begin{array}{c}\text { Probability of } \\
\text { occurrence of } \\
\text { harm(P) }\end{array}$ & \multicolumn{4}{|c|}{ Severity of harm (S) } \\
\cline { 2 - 5 } & $\begin{array}{c}\text { Minor } \\
(\mathrm{S} 1=1)\end{array}$ & $\begin{array}{c}\text { Moderate } \\
(\mathrm{S} 2=2)\end{array}$ & $\begin{array}{c}\text { Serious } \\
(\mathrm{S} 3=4)\end{array}$ & $\begin{array}{c}\text { Catastrophic } \\
(\mathrm{S} 4=5)\end{array}$ \\
\hline $\begin{array}{c}\text { Remote } \\
(\mathrm{P} 1=1)\end{array}$ & $\begin{array}{c}\mathrm{I} \\
(\mathrm{RI}=2)\end{array}$ & $\begin{array}{c}\mathrm{I} \\
(\mathrm{RI}=3)\end{array}$ & $\begin{array}{c}\mathrm{II} \\
(\mathrm{RI}=5)\end{array}$ & $\begin{array}{c}\mathrm{II} \\
(\mathrm{RI}=6)\end{array}$ \\
\hline $\begin{array}{c}\text { Unlikely } \\
(\mathrm{P} 2=3)\end{array}$ & $\begin{array}{c}\mathrm{I} \\
(\mathrm{RI}=4)\end{array}$ & $\begin{array}{c}\mathrm{II} \\
(\mathrm{RI}=5)\end{array}$ & $\begin{array}{c}\mathrm{III} \\
(\mathrm{RI}=7)\end{array}$ & $\begin{array}{c}\mathrm{III} \\
(\mathrm{RI}=8)\end{array}$ \\
\hline $\begin{array}{c}\text { Likely } \\
(\mathrm{P} 3=5)\end{array}$ & $\begin{array}{c}\mathrm{II} \\
(\mathrm{RI}=6)\end{array}$ & $\begin{array}{c}\mathrm{III} \\
(\mathrm{RI}=7)\end{array}$ & $\begin{array}{c}\mathrm{IV} \\
(\mathrm{RI}=9)\end{array}$ & $\begin{array}{c}\mathrm{IV} \\
(\mathrm{RI}=10)\end{array}$ \\
\hline $\begin{array}{c}\text { Very likely } \\
(\mathrm{P} 4=7)\end{array}$ & $\begin{array}{c}\mathrm{III} \\
(\mathrm{RI}=8)\end{array}$ & $\begin{array}{c}\mathrm{IV} \\
(\mathrm{RI}=9)\end{array}$ & $\begin{array}{c}\mathrm{IV} \\
(\mathrm{RI}=11)\end{array}$ & $\begin{array}{c}\mathrm{IV} \\
(\mathrm{RI}=12)\end{array}$ \\
\hline
\end{tabular}

Table 4 Levels of hygiene risk

\begin{tabular}{|c|l|}
\hline Risk level & \multicolumn{1}{|c|}{ Interpretation of risk level } \\
\hline $\begin{array}{c}\mathrm{I} \\
(\mathrm{RI}=2 \sim 4)\end{array}$ & $\begin{array}{l}\text { Acceptable risk } \\
\text { (Negligible) }\end{array}$ \\
\hline $\mathrm{II}$ & $\begin{array}{l}\text { Tolerable risk } \\
(\mathrm{RI}=5 \sim 6)\end{array}$ \\
\hline $\mathrm{Low})$ \\
\hline $\mathrm{RI}=7 \sim 8)$ & $\begin{array}{l}\text { Intolerable risk } \\
\text { (Medium) }\end{array}$ \\
\hline $\mathrm{IV}$ & $\begin{array}{l}\text { Unacceptable risk } \\
\text { (High) }\end{array}$ \\
\hline $\mathrm{RI}=9 \sim 12)$
\end{tabular}

\section{5. 結 語}

食品は他の工業製品と異なり，消費者が直接体内に取り込むため，我が国における食品の衛生性に対する社会 的要求は高く，世界的にも極めて高いレベルと言える. それを示す 1 例として「パンに焦げたパン生地片が付着 しただけでも消費者から “異物混入”として苦情が寄せられるので，“焦げ”を異物として管理し，取り除かなけ ればならない」等の話を機械ユーザより聞く程である.

食品関連産業界では機械ユーザをはじめとし，機械メーカ等を含む多くの事業者は，上述に示す我が国におけ る社会的要求を満たすために，衛生リスク低減活動に取り組んでいる．本リスクアセスメントプロセスのモデル は，可能な限り機械ユーザが被る可能性のある経済的損失一の考慮が “衛生的保護方策”として求められている 現実を踏まえ，実務として利用可能な手法となるよう心がけた。

また，衛生 B 規格は，衛生リスクに対する各種の保護方策を示寸が，その多くは「洗浄可能」「迅速にアクセ ス可能」のような漠然とした性能しか示さない，洗浄性に関連寸る表面仕上げや，内角 $\mathrm{R}$ の寸法等は，要求レベ ルにより要するコストが大きく異なる．本論文にて示す評価レべルを定めたことにより，具体的な保護方策の構 造をタイプC 規格として示すことができると期待される.

\section{文献}

(1) ISO 12100-1 : Safety of machinery - Basic concepts, general principles for design - Part 1: Basic terminology, methodology, (2003).

(2) ISO 14159 : Safety of machinery - Hygiene requirements for the design of machinery, (2002).

（3）中央労働災害防止協会編，安全衛生年鑑，平成 17 年版，(2006)，pp.216-219，中央労働災害防止協会.

(4) ISO14121-1 : Safety of machinery - Risk assessment - Part 1: Principles, (2007).

（5）経済産業省産業省経済産業政策局調查統計部編，平成 18 年工業統計表，産業編，(2006)，p.246，財団法人経済産 業調査会.

(6) ISO/TR 14121-2 : Safety of machinery - Risk assessment - Part 2: Practical guidance and examples of methods, (2007).

(7) ANSI B11.TR3, Risk assessment and risk reduction - A guide to estimate, evaluate and reduce risks associated with machine tools, (2000).

（8）AIU 保険編，CPI の事故例，(2008)，株式会社さくらアソシエイト.

（9）内閣府国民生活局，食品・製品等のリコールに関する分野横断的指針についての調查研究，(2008)，p.101.

（10）経済産業省産経済業政策局調查統計部編，平成 18 年工業統計表，企業統計編，(2009)，p.41，財団法人経済産業調 查会.

(11) ISO/IEC Guide 51, Safety aspects - Guidelines for their inclusion in standards, (2004).

(12) IEC61508-5 : Functional safety of electrical / electronic / programmable electronic safety-related systems - Part 5: Examples of methods for the determination of safety integrity levels,(1998). 